International Journal of Engineering \& Technology, $7(2.29)(2018) 927-932$
International Journal of Engineering \& Technology
SPC
Website: www.sciencepubco.com/index.php/IJET
Research paper

\title{
Effect of Curing Method on Properties of Lightweight Foamed Concrete
}

\author{
Bishir Kado ${ }^{1}$, Shahrin Mohammad ${ }^{2 *}$, Yeong Huei Lee ${ }^{3}$, Poi Ngian Shek ${ }^{4}$, Mariyana Aida Ab Kadir ${ }^{5}$ \\ 1,2,3,5Faculty Of Civil Engineering, Universiti Teknologi Malaysia, 81310 Johor Bahru, Johor, Malaysia. \\ ${ }^{4}$ Construction Research Centre (UTM-CRC), Universiti Teknologi Malaysia, 81310 Johor Bahru, Johor, Malaysia. \\ *Corresponding Author E-Mail: Shahrin@Civil.My
}

\begin{abstract}
Lightweight construction is aimed to achieve a sustainable feature by reducing transportation frequency and construction materials usage during construction phase. Lightweight precast concrete may serve an alternative for the lightweight construction. There are rarely application can be found for structural members as lightweight panels always to be used for secondary or non-load bearing members. This paper presents an experimental study on properties (compressive strength, splitting tensile strength, water absorption) of lightweight foamed concrete (LFC) at two different curing methods. LFC with densities of 1500,1700 , and $1800 \mathrm{~kg} / \mathrm{m}^{3}$, cementsand ratio of 2:1 and water-cement ratio of 0.5 were investigated. The results showed LFC can be produced with the properties of density range of 1500 to $1800 \mathrm{~kg} / \mathrm{m}^{3}$ and corresponding compressive strength of 10 to $39 \mathrm{MPa}$. The higher the density of LFC, the less the water absorption for all the curing method considered, the highest and the lowest water absorption was $11.3 \%$ and $2.0 \%$ for 1500 $\mathrm{kg} / \mathrm{m}^{3}$ cured in water and $1800 \mathrm{~kg} / \mathrm{m}^{3}$ cured in air respectively. Compressive strength of LFC increases with age and density while water cured LFC has high compressive strength. Splitting tensile strength increases with density of LFC, but air cured LFC has more splitting tensile strength than water cured of the same density. The highest splitting tensile strength recorded was $3.92 \mathrm{MPa}$ for 1800 $\mathrm{kg} / \mathrm{m}^{3}$ cured in air, which was about $16 \%$ of its compressive strength at 28 days of curing age. These properties are important and can be applied to LFC precast structural members with air or water curing method which have less references for LFC in structural usage.
\end{abstract}

Keywords: Lightweight; foamed concrete; curing; density; strength

\section{Introduction}

One of the advantages of lightweight concrete in construction projects is to reduce the self-weight of the concrete structure; thereby reducing the size of the structural members such as columns, beams, foundations and other load bearing members [1]. Foamed concrete is an aerated light-weight concrete produced by mixing cement, sand and water to form cement paste, the cement paste then mixed with pre-formed stable foam produced from foam generator. Foamed concrete can be designed to have any density within the range of $300-1850 \mathrm{~kg} / \mathrm{m}^{3}$ dry density [2]. Lightweight foamed concrete (LFC) were commonly used for void filling, roof insulation, trench reinstatement, bridge abutment, thermal insulation, road and pavement sub-bases, precast blocks and panels [3]. Lightweight, ease of fabrication, durability and cost effectiveness are some of the advantages of LFC that attracts a lot of attention from industry [4].

Lim et. al. [5] presented other advantages such as excellent thermal and sound insulation, low density, self-compacting, and high flow ability made LFC commonly used for structural and non-structural purpose by construction industry. Mydin [6] studied the possibility of using LFC in load bearing composite wall panels for low rise structure. The result showed that it is possible to design composite walling system to resist floor loads using LFC in a low rise residential structure. Investigations on strength of composite sections with foamed and lightweight concrete was conducted on circular and square concrete filled steel tube columns and simply supported short beams. The result shows that LFC contribution to squash load is insignificant, while its contribution to the flexural strength is significant [7].

A lot of studies were carried out on LFC and its application, but very few researches are available on structural LFC and its application; as such the properties of structural LFC need to be investigated thoroughly. The purpose of this paper is to presents the study on properties of structural light weight foam concrete at different curing method. When LFC is being used as an infill material in composite structures, in most cases, it is not possible to cure the LFC with water (for example in concrete filled steel tube columns). Therefore, LFC properties cured in water and Air need to be explored. Experimental investigations were carried out on $1500 \mathrm{~kg} / \mathrm{m}^{3}$, $1700 \mathrm{~kg} / \mathrm{m}^{3}$, and $1800 \mathrm{~kg} / \mathrm{m}^{3} \mathrm{LFC}$ densities at $2: 1$ cement-sand ratio and water-cement ratio of 0.5 .

\section{Previous Investigation on Structural Prop- erties of LFC}

The amount of air content in LFC, resulting from mixing with foam, significantly affect the strength and other properties. LFC gained a lot of popularity in some countries like Japan, United Kingdom and Europe [8]. Lightweight concretes have been classified based on its properties [9], the classification is presented in Table 1.

Table 1: Classification of light-weight concrete based on concrete properties 


\begin{tabular}{|l|l|l|l|}
\hline $\begin{array}{l}\text { Classification of light- } \\
\text { weight concretes. Prop- } \\
\text { erty }\end{array}$ & Structural & $\begin{array}{l}\text { Structural / } \\
\text { insulating }\end{array}$ & Insulating \\
\hline $\begin{array}{l}\text { Compressive strength } \\
{[\mathrm{MPa}]}\end{array}$ & $>15.0$ & $>3.5$ & $>0.5$ \\
\hline $\begin{array}{l}\text { Coefficient of thermal con- } \\
\text { ductivity [W/m.K] }\end{array}$ & - & $<0.75$ & $<0.30$ \\
\hline $\begin{array}{l}\text { Approximate density range } \\
{[\mathrm{kg} / \mathrm{m} 3]}\end{array}$ & $1600-2000$ & $<1600$ & $<<1450$ \\
\hline
\end{tabular}

Concrete must be subjected to appropriate environment at the early stages of hardening for achieving a good quality; curing is the procedures followed for promoting cement hydration. Generally, control of temperature and of the movement of moisture in to and from the concrete is termed curing procedures. They both affect the strength of concrete, temperature movement in to and from the concrete affect both strength and durability of concrete. Concrete curing procedures varies depending on the conditions on site and on the size, shape, and position of the concrete member considered. The effect on curing conditions on the strength of concrete is lower in the air entrained than non-air entrained concrete [10].

The properties of structural LFC have been investigated using fly ash, polypropylene fiber and silica fume $[11,12]$. Sand was replaced by fly ash in the mix; silica fume and polypropylene fiber were added to enhance the properties of LFC. Compressive strength and splitting tensile strength were among the properties investigated. It was reported that a compressive strength of 10-50 MPa can be achieved with foam concrete density of $800-1500 \mathrm{~kg} / \mathrm{m}^{3}$ using silica fume and polypropylene fiber. Addition of silica fume and polypropylene fiber significantly enhanced compressive strength of LFC Propylene fiber also improves the splitting tensile strength.

Experimental study was carried out to determine the effects on properties of foam concrete by replacing cement content up to $75 \%$ by weight with both classified and unclassified fly ash [13]. The results showed the porosity of the LFC cured for one year was dependent on dry density of the concrete, not on amount or type of fly ash used. Permeability of LFC was determined by water vapour permeability, water absorption, and the amount of water absorbed doubled that of corresponding cement paste; also it did not depends on the entrained air volume, amount or type of fly ash.

Properties of fresh and hardened foamed concrete were studied [5] Various sand gradations ranging from $2.36 \mathrm{~mm}$ to $0.6 \mathrm{~mm}$ were used to produce the foamed concrete with density of $1300 \mathrm{~kg} / \mathrm{m}^{3}$, the specimens were cured in water and air. The results showed that the sample made with finer sand produced higher compressive strength, flexural toughness and flexural strength than the sample made with coarser sand. Also, for better compressive and flexural strength development, total water curing is required up to 56 days than curing in air

The properties of LFC were investigated by replacing the cement and fine sand with silica fume and fly ash [14]. The study was carried out on 1300 to $1900 \mathrm{~kg} / \mathrm{m}^{3}$ concrete density; among the properties studied are consistencies, mechanical and thermal properties. The results showed that 6 to $23 \mathrm{MPa}$ compressive strength of foam concrete can be achieved by replacing some amount of the cement and sand with silica fume and fly ash.

Effects of various dimensions and profiles on the axial compressive strength of LFC were investigated [15]. The mixes with dry target density of $1250 \mathrm{~kg} / \mathrm{m}^{3}$ were prepared. Cubes, cylinders and prism of various dimensions were casted and cured for 7 and 28 days. All the samples were cured inside plastic sheet for curing duration. It was concluded that the cylinder specimen has ha small change in compressive strength when length to diameter ratio change from 1.0 to 2.0 as compared to cube specimen. Cube specimens carried more load than cylinder specimen when all the dimension and volume were identical [15]

An experimental study was performed on compressive strength and tensile strength of LFC containing pulverized bone as partial replacement of cement [16]. Among the properties investigated are workability, testing and plastic density, compressive strength, and tensile strength at the designated density of $1600 \mathrm{~kg} / \mathrm{m}^{3}$; the pulverized bone used in the mix was varied from 0 to $20 \%$ at a constant interval of $5 \%$. Workability of fresh foam concrete was obtained from the slump test, $150 \mathrm{~mm}$ cubes were used for the determination of compressive strength and testing density, $150 \times 150 \times 750 \mathrm{~mm}$ unreinforced beams were used to obtain flexural strength and $150 \times$ $300 \mathrm{~mm}$ cylinders were used for splitting tensile strength. Foamed concrete samples were made with and without pulverized bone. All the samples were cured in water and air for 28 days. From the results, for all the pulverized bone replacement levels, air cured samples produced higher strength than the water cured samples. And there is no significant difference between the samples with and without pulverized bone replacement. The investigation was concluded LFC can be applied for structural applications.

An investigation was performed on LFC made with sand and without sand, targeted $1900 \mathrm{~kg} / \mathrm{m}^{3}$ plastic density [17]. It was concluded that the density of foam concrete depends on the amount of foam added in the foam concrete mixture; the higher the foam in the mixture, the less the density of the foam concrete. Also fine aggregate effectively increase the compressive strength of foam concrete. Panels made of higher density foam concrete can be demoulded after 24 hours, but panels made of lower density foam concrete needs at least 3 days before demolding. Water absorption of light weight foam concrete is less than $5 \%$ by volume. Compressive strength of foam concrete increases with age, and the increase is virtually linear up to the first one year. The strength development of foam concrete is higher than in normal weight concrete, as such curing method must ensure moisture retention for long period in foam concrete panels and building blocks.

Applications of LFC in building and construction are on increase. Recently, they are been used as structural materials in building houses and schools in countries like Russia, Libya, Indonesia, Brazil, Egypt, Singapore, Saudi Arabia, and Mexico. SMART tunnel project in Kuala Lumpur was the first major applications of foamed concrete in Malaysia [18]. Foam concrete block with density of around $1800 \mathrm{Kg} / \mathrm{m}^{3}$ with 28 days compressive strength of about 3 $\mathrm{MPa}$ were used. The foam concrete blocks serves as a protection to the diaphragm wall for tunneling machine [18]. The applications of LFC were summarized [19] and depicted in Table 2.

Table 2: LFC applications based on its density

\begin{tabular}{|l|l|}
\hline Density $\left(\mathbf{k g} / \mathbf{m}^{\mathbf{3}}\right)$ & Application \\
\hline $300-600$ & $\begin{array}{l}\text { Replacement of existing soil, soil stabilization, raft } \\
\text { foundation }\end{array}$ \\
\hline $500-600$ & $\begin{array}{l}\text { Currently being used to stabilize a redundant, ge- } \\
\text { otechnical } \\
\text { Rehabilitation and soil settlement. Road construc- } \\
\text { tion }\end{array}$ \\
\hline $600-800$ & $\begin{array}{l}\text { Widely used in void filling, as an alternative to } \\
\text { granular fill. Some } \\
\text { such applications include filling of old sewerage } \\
\text { pipes, wells, } \\
\text { basement and subways }\end{array}$ \\
\hline $800-900$ & $\begin{array}{l}\text { Primarily used in production of blocks and other } \\
\text { non-load bearing } \\
\text { building element such as balcony railing, parti- } \\
\text { tions, parapets, etc }\end{array}$ \\
\hline $1100-1400$ & $\begin{array}{l}\text { Used in prefabrication and cast-in place wall, either } \\
\text { load bearing or } \\
\text { non-load bearing and floor screeds. }\end{array}$ \\
\hline $1100-1500$ & Housing applications \\
\hline $1600-1800$ & $\begin{array}{l}\text { Recommended for slabs and other load bearing } \\
\text { building element } \\
\text { where higher strength required }\end{array}$ \\
\hline
\end{tabular}

The versatile characteristic of LFC application were explained by many researchers, notably in [20,21]: Lightweight: The density is about $50 \%$ to $80 \%$ of the normal weight concrete density. Due to its low density, it reduces the weight of a structural element by about $25 \%$. These will results in total decrease in weight of a structure to about 30 to $40 \%$ when a normal weight concrete is substituted by LFC in construction; Heat and Sound Insulation: Because of the uniform pores present in the foam concrete, it prevents heat and cold exchange by controlling the air. It also has very low thermal conductivity of about $0.1 \mathrm{~W} \mathrm{~K} / \mathrm{m}$ for common foamed concrete in practice, which is around 14 times less than that of normal weight concrete. Sound insulation is due to the presence of distributed closed pores in the foamed concrete, which make it to have very 
good performance in sound movement; Fire resistance: The constituent materials of foamed concrete do not have chemical characteristic of spontaneous combustion and the presence of distributed pores in the foamed concrete make it to have good fire resistance; Seismic performance: Foamed concrete is light in weight, having less density and modulus of elasticity when compared to normal weight concrete. It can easily absorb the impact of load when it is subjected to earthquake wave; and Frost resistance: porous nature of light weight foamed concrete making it to resist frost action on concrete.

The possibility of using LFC in load bearing composite wall panels for low rise structure has been studied $[22,23]$. LFC density of $1000 \mathrm{~kg} / \mathrm{m}^{3}, 2: 1$ cement-sand ratio, and water-cement ratio of 0.5 were used for the research. The result shows that it is possible to design composite walling system to resist floor loads using LFC in a low rise residential structure.

\section{Experimental Investigation}

\subsection{Materials}

Ordinary Portland cement, river sand, tap water, silica fume and synthetic foaming agent were used for this study. Silica fume were used as additive in the mix. Silica fume can make a meaningful increase of foamed concrete compressive strength up to at most $25 \%$. The increase in compressive strength depends on the volume of foam added. Therefore, with appropriate volume of foam added, foamed concrete strength can significantly be increased [12]. Ordinary Portland cement (Type I): ordinary Portland cement from Tasek Corporation Berhad was used for this research. The chemical composition of ordinary Portland cement used is presented in Table 3

Sand: Preferred sand is mostly from the river, for this research, river sand was used which is free from any contamination. Raw (unsieved) sand was used in this research, which was got directly from the river contains no impurities.

Water: potable water was used for the foam concrete mixing and curing. Water for concrete mix should be free from acids, oils, salts, organic matter and alkalis. The oil used in the mould will not have harmful effect on the foamed concrete, because the foams are already embedded in mortar.

Silica fume: The Silica fume used for this research was densified silica fume for high performance concrete manufactured by Greco Chem. Company. Its specific gravity ranges between 2.1 to $2.4 \mathrm{~kg} / \mathrm{lt}$ and of bulk density $550-650 \mathrm{~kg} / \mathrm{m}^{3}$. Typical dosage rates ranges from 5 to $10 \%$ by weight of cement. Chemical composition of the silica fume is presented in Table 3.

Foam: Foam agents are made to produce stable foam (air bubbles) that resist applied forces when mixing, casting and curing of foam concrete. Foam agent solution is made up of surfactant one part and 5 to 20 parts water.

Table 3: Chemical composition of ordinary Portland cement used

\begin{tabular}{|l|l|l|l|}
\hline \multirow{2}{*}{ S/N } & \multirow{2}{*}{ Oxide } & Composition (\%) \\
\cline { 3 - 4 } & & OPC & Silica fume \\
\hline 1 & $\mathrm{SiO}_{2}$ & 21.28 & 90 \\
\hline 2 & $\mathrm{Al}_{2} \mathrm{O}_{3}$ & 5.60 & 1.2 \\
\hline 3 & $\mathrm{Fe}_{2} \mathrm{O} 3$ & 3.36 & 2.0 \\
\hline 4 & $\mathrm{CaO}$ & 64.64 & 1.0 \\
\hline 5 & $\mathrm{MgO}$ & 2.06 & 0.6 \\
\hline 6 & $\mathrm{SO}_{3}$ & 2.14 & 0.5 \\
\hline 7 & $\mathrm{Na}_{2} \mathrm{O}$ & - & 0.8 \\
\hline 8 & $\mathrm{~K}_{2} \mathrm{O}$ & - & 0.8 \\
\hline 9 & $\mathrm{Total}$ alkalis & 0.05 & - \\
\hline 10 & Insoluble residue & 0.22 & - \\
\hline 11 & Loss on ignition & 0.64 & 6.0 \\
\hline
\end{tabular}

\subsection{Mix Design}

Cement- sand ratio of 2:1 and water-cement ratio of 0.5 were used for all the LFC mix. The above ratios were found producing comparatively good compressive strength and sufficient workability respectively [24, 25]. Properties of LFC samples of $1500 \mathrm{~kg} / \mathrm{m}^{3}$, $1700 \mathrm{~kg} / \mathrm{m}^{3}$ and $1800 \mathrm{~kg} / \mathrm{m}^{3}$ densities were investigated. All the samples were casted in structures and materials laboratory Faculty of Civil Engineering, Universiti Teknologi Malaysia. Table 4 presents details of mix proportions for the LFC. Silica fume was added as $10 \%$ of cement weight in each mix.

Table 4: Mix constituents for LFC

\begin{tabular}{|c|c|c|c|c|}
\hline $\begin{array}{c}\text { Target dry } \\
\text { density, } \mathrm{kg} / \mathrm{m}^{3}\end{array}$ & $\begin{array}{c}\text { Cement, } \\
\mathrm{kg} / \mathrm{m}^{3}\end{array}$ & $\begin{array}{l}\text { Sand, } \\
\mathrm{kg} / \mathrm{m}^{3}\end{array}$ & $\begin{array}{l}\text { Water, } \\
\mathrm{kg} / \mathrm{m}^{3}\end{array}$ & $\begin{array}{c}\text { Silica fume, } \\
\mathrm{kg} / \mathrm{m}^{3}\end{array}$ \\
\hline 1500 & 750 & 375 & 375 & 75 \\
\hline 1700 & 850 & 425 & 425 & 85 \\
\hline 1800 & 900 & 450 & 450 & 90 \\
\hline
\end{tabular}

Mortar mix was prepared in the concrete mixer before mixing with stable foam. Stable foam was prepared by diluting synthetic foaming agent in water at a ratio of 1:30 synthetic foaming agent to water ratio by volume. The solution was then compressed by pressurized air in the foam generator there by producing the stable foam at a density of $45 \mathrm{~kg} / \mathrm{m}^{3}$. Stable foam produced from the foam generator was weighed in a container of known volume. The density of cement mortar was then measured to obtain a guide for the accurate amount of stable foam to be added. Required amount of stable foam was then added to the cement mortar and mixed in the concrete mixer. The density of the fresh foam concrete was then measured and maintained within the range of $\pm 50 \mathrm{~kg} / \mathrm{m}^{3}$.

\subsection{Properties of LFC Specimens}

Cubes size of $70 \times 70 \times 70 \mathrm{~mm}$ and cylinder mould of size $100 \mathrm{~mm}$ diameter and $200 \mathrm{~mm}$ height were used throughout this research. Both the cubes and cylinders were cured in water and air for 7, 28 and 56 days. All tests were carried out in triplicates, and the average values were reported.

\subsubsection{Density}

Fresh density of mortar and LFC mix was measured prior to casting. Dry density of LFC samples cured in water and air for 7, 28 and 56 days were obtained in accordance with BS EN 12390- 7 [26].

\subsubsection{Water Absorption}

Cubes LFC specimen was used for water absorption test in accordance with BS 1881 - 122 [27]. Specimens were cured in water and air. The samples were oven dried for 72 hours at $105 \pm 5^{\circ} \mathrm{C}$. It was then removed and cools for 24 hours in an air tight dry vessel. The cool sample was then weigh and immersed in water for 30 minutes, mass of the sample after immersion in water then recorded. The water absorption was calculated as Eq. 1. The water absorption test was carried out at 28 days of curing, and the samples were spaced for oven drying as shown in Figure 1.

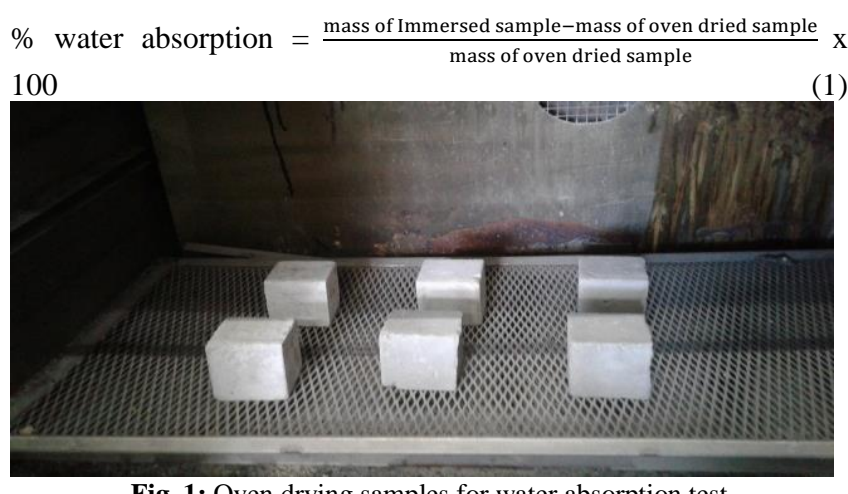

Fig. 1: Oven drying samples for water absorption test

\subsubsection{Compressive and Splitting Tensile Strength}

Total of 81 cubes and 18 cylinders of LFC were tested and cured for 7, 28 and 56 days in water and air. Samples was then removed 
and tested for compression in accordance to BS EN 12390-3 [28]. Cylindrical specimen was used for this test in accordance to BS EN 12390-6 [29] as shown in Figure 2. The maximum fracture load was recorded, and the splitting tensile strength was calculated using the relation of Eq. 2.

$\mathrm{F}_{\mathrm{ct}}=\frac{2 F}{\pi L D}$

where $\mathrm{F}_{\mathrm{ct}}$ is the splitting tensile strength in $\mathrm{MPa}, \mathrm{F}$ is the maximum load in N, L is the height of the specimen in $\mathrm{mm}$, and $\mathrm{D}$ is the diameter of the specimen in $\mathrm{mm}$.

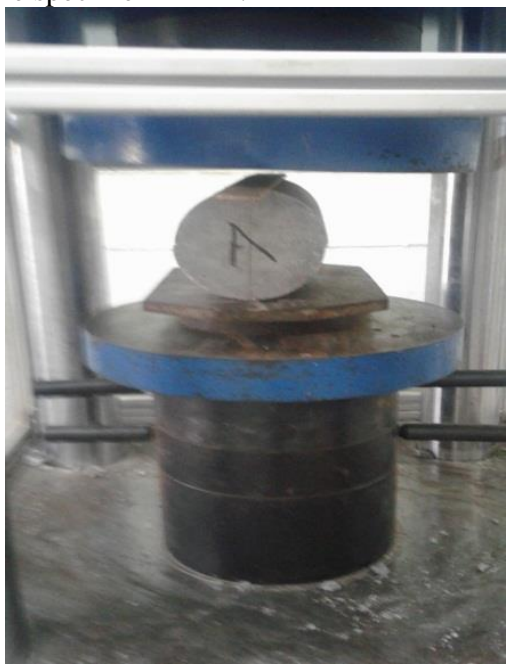

Fig. 2: Splitting tensile test set-up

\section{Results and Discussion}

\subsection{Fresh Density}

It can be seen from Table 5 that the stability of LFC tends to unity for all the target densities. It shows that the foam was able to mix with mortar thoroughly without collapsing. Stability is the ratio of fresh density to hardened density of LFC. Therefore, stability of foam concrete depends on quality of foam used.

Consistency is the ratio of fresh density to the designated density. Consistency depends on the amount of foam added to the LFC mix. For this research, the consistency tends to unity. The density of LFC depends on stability and consistency of the mix, and the strength of LFC depends on density, as such stability and consistency of LFC mix affects the strength of LFC.

\begin{tabular}{|c|c|c|c|c|c|}
\hline $\begin{array}{l}\text { Tar- } \\
\text { geted } \\
\text { density, } \\
\mathrm{kg} / \mathrm{m}^{3}\end{array}$ & $\begin{array}{l}\text { Curing } \\
\text { condi- } \\
\text { tion }\end{array}$ & $\begin{array}{l}\text { Fresh } \\
\text { den- } \\
\text { sity, } \\
\text { kg/m } \text { m }^{3}\end{array}$ & $\begin{array}{l}\text { Hard- } \\
\text { ened } \\
\text { density, } \\
\mathrm{kg} / \mathrm{m}^{3}\end{array}$ & $\begin{array}{l}\text { Con- } \\
\text { sistency }\end{array}$ & $\begin{array}{l}\text { Stabil- } \\
\text { ity }\end{array}$ \\
\hline \multirow{2}{*}{1500} & Water & \multirow{2}{*}{1545} & 1604 & \multirow{2}{*}{1.03} & 0.96 \\
\hline & Air & & 1589 & & 0.97 \\
\hline \multirow{2}{*}{1700} & Water & \multirow{2}{*}{1749} & 1793 & \multirow{2}{*}{1.02} & 0.98 \\
\hline & Air & & 1724 & & 1.01 \\
\hline \multirow{2}{*}{1800} & Water & \multirow{2}{*}{1850} & 1909 & \multirow{2}{*}{1.02} & 0.97 \\
\hline & Air & & 1874 & & 0.99 \\
\hline
\end{tabular}

\subsection{Water Absorption}

Water absorption of LFC samples cured in water is higher than that of LFC samples cured in air for all the densities investigated in this research. The water absorption of LFC with density of $1800 \mathrm{~kg} / \mathrm{m}^{3}$ is $4.0 \%$ and $2.0 \%$ for water and air cured LFC respectively, it is less than $5.2 \%$ and $2.9 \%$ water absorption at $1700 \mathrm{~kg} / \mathrm{m}^{3}$ for water and air cured respectively. LFC sample with $1500 \mathrm{~kg} / \mathrm{m}^{3}$ density has $11.3 \%$ and $9.0 \%$ water absorption for water and air cured respectively, which is higher than that of $1700 \mathrm{k} / \mathrm{m}^{3}$ and $1800 \mathrm{~kg} / \mathrm{m}^{3} \mathrm{densi-}$ ties.
From the result in Figure 3, it can be shown that the higher the density the less the water absorption. Density of LFC depends on amount of foam added, the more the foam and the less the density and also the porosity, and the higher the porosity the more the water absorption.

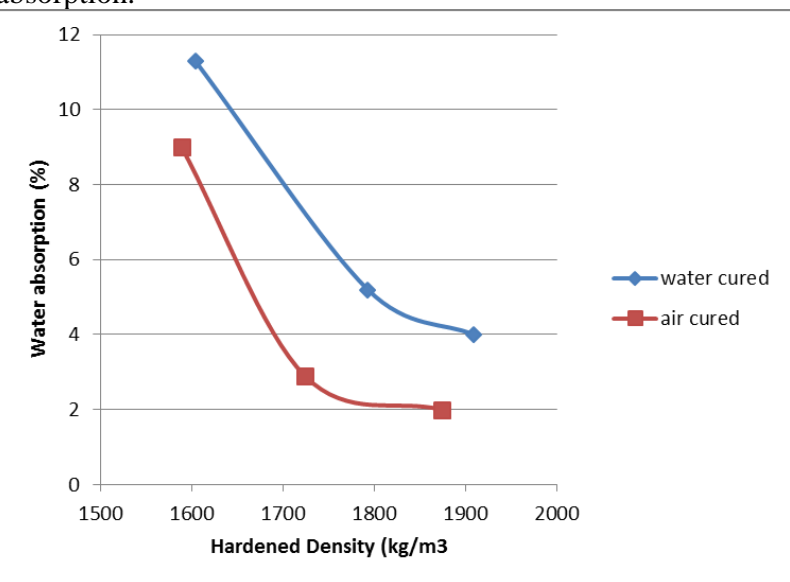

Fig. 3: Water absorption against hardened density of LFC cured in water and air

\subsection{Compressive Strength}

Compressive strength of LFC increases with increase in curing age for both densities and different curing condition of LFC as shown in Figure 4 and Table 6 . The minimum compressive strength was recorded for LFC of $1500 \mathrm{~kg} / \mathrm{m}^{3}$ cured in air as $10.01 \mathrm{MPa}, 12.67$ $\mathrm{MPa}$ and 13.20 MPa for 7, 28, and 56 days respectively; the increase in strength is about $26.6 \%$ and $4 \%$ at 7 to 28 days and 28 to 56 days respectively. While the highest strength recorded for $1800 \mathrm{~kg} / \mathrm{m}^{3}$ LFC cured in water was 27.11 MPa, 35.21 MPa, and 39.38 MPa for 7,28 , and 56 days respectively; which represent $29.9 \%$ and $11.8 \%$ increase in strength between 7 to 28 days and 28 to 56 days respectively. Foamed concrete compressive strength displayed continuous increase with age. The rate at which the compressive strength developed was initially greater and decrease with increase in age.

The compressive strength of LFC cured in water for all the densities considered is higher than that of the LFC sample cured in air at all the curing ages as shown in Figure 5. The increase in strength is high for when the density of LFC is also high. The compressive strength of LFC at 7, 28 and 56 days cured in water is $27.11,35.21$, and 39.38 MPa respectively; while that of LFC cured in air at 7, 28, and 56 days is $21.14,24.05$, and $25.05 \mathrm{MPa}$ respectively.

Table 6: Compressive strength of LFC at different curing method for the densities considered

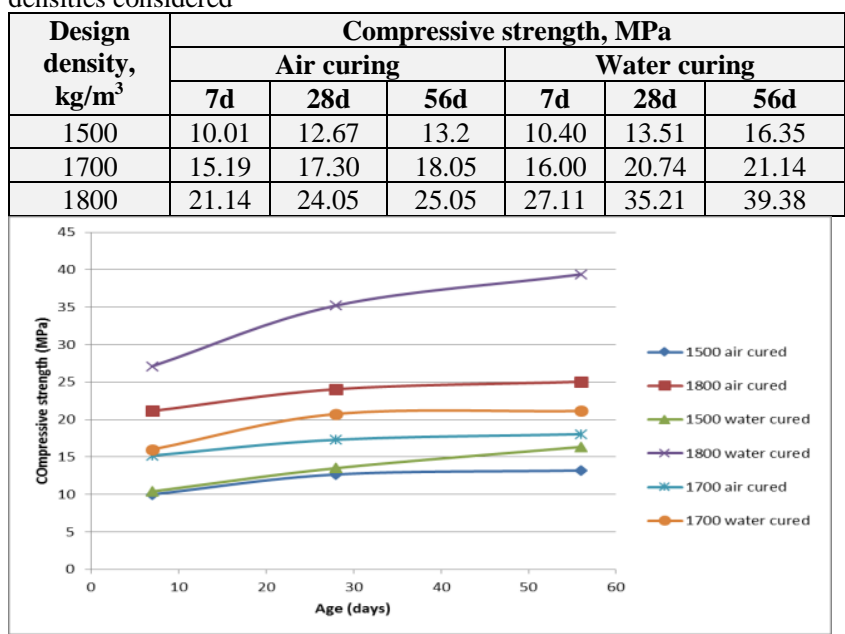

Fig. 4: Compressive strength against curing age of LFC 


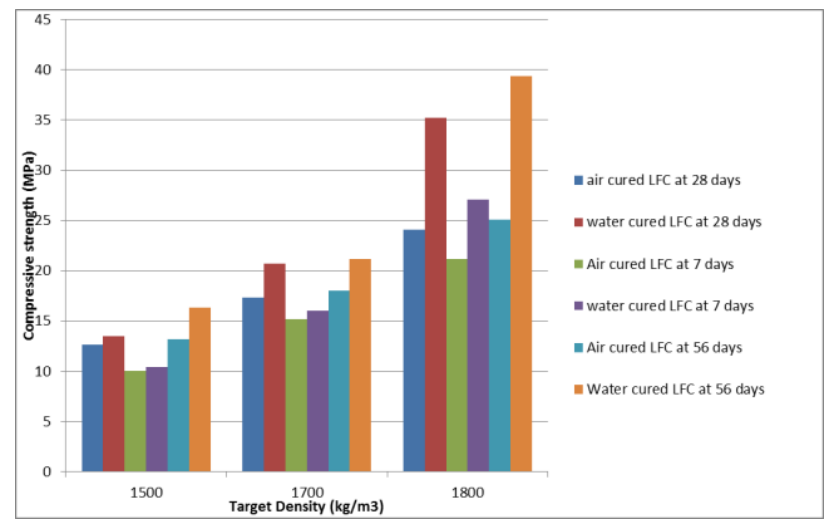

Fig. 5: Compressive strength against design density of LFC

\subsection{Splitting Tensile Strength}

Splitting tensile strength of LFC increases with increase in density for both water and air cured LFC specimen at 28 days curing. From Figure 6 , it can be seen that the splitting tensile strength of LFC cured in air increases sharply with increase in density than LFC cured in water. The highest and the lowest splitting tensile strength recorded is $3.92 \mathrm{MPa}$ and $1.32 \mathrm{MPa}$ for $1800 \mathrm{~kg} / \mathrm{m}^{3}$ air cured and $1500 \mathrm{~kg} / \mathrm{m}^{3}$ water cured LFC respectively. The values recorded are above $0.17 \mathrm{MPa}$ minimum value as recommended by ASTM C86991 [30] for lightweight concrete. From Table 7, splitting tensile strength ranges between 8 to $17 \%$ of the compressive strength of LFC at 28 days water and air curing.

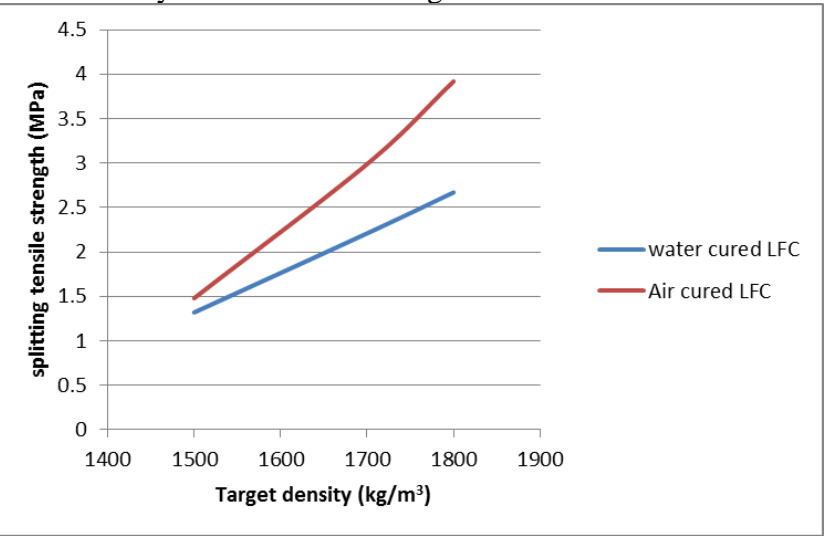

Fig. 6: Splitting tensile strength against target density at 28 days curing

Table 7: Comparison between Splitting tensile strength and Compressive strength of LFC at 28 days curing

\begin{tabular}{|c|c|c|c|c|}
\hline $\begin{array}{c}\text { Target } \\
\text { density, } \\
\mathbf{k g} / \mathbf{m}^{\mathbf{3}}\end{array}$ & \multirow{2}{*}{$\begin{array}{c}\text { Curing } \\
\text { method }\end{array}$} & $\begin{array}{c}\text { Compressive } \\
\text { strength, fc }\end{array}$ & $\begin{array}{c}\text { Splitting } \\
\text { tensile } \\
\text { strength, fs }\end{array}$ & $\begin{array}{c}\text { Ratio, } \\
\text { fs/fc }\end{array}$ \\
\hline \multirow{2}{*}{1500} & water & 13.51 & 1.32 & 0.10 \\
\cline { 2 - 5 } & air & 12.67 & 1.48 & 0.12 \\
\hline \multirow{2}{*}{1700} & water & 20.74 & 2.21 & 0.11 \\
\cline { 2 - 5 } & air & 17.30 & 2.99 & 0.17 \\
\hline \multirow{2}{*}{1800} & water & 35.21 & 2.67 & 0.08 \\
\cline { 2 - 5 } & air & 24.05 & 3.92 & 0.16 \\
\hline
\end{tabular}

\section{Conclusions}

This study presented the experimental investigation on LFC properties at different curing method. From the results, the following conclusions can be made:

(i) The density affects other properties of fresh and hardened LFC. Air cured LFC is more stable than water cured sample for all the densities considered.

(ii) It can be seen that the higher the density of LFC, the less the water absorption for both the water and air cured LFC. And water cured LFC has more water absorption than air cured LFC of the same design density. (iii) Compressive strength of LFC increases with age for both water and air cured LFC. But the strength of LFC cured in water is high than that of LFC cured in air of the same design density. Also, the higher the density of LFC, the more the compressive strength for both the air and water cured samples.

(iv) Splitting tensile strength of LFC is proportional to its designated density. Air cured LFC has high splitting tensile strength than water cured LFC for all the designated densities considered at 28 days curing.

These information are important for the development of precast LFC in order to achieve structural behaviour towards sustainable construction system.

\section{Acknowledgements:}

This research work is supported by FRGS grant of 4F763 from Ministry of Higher Education Malaysia (MOHE). The supports from both Universiti Teknologi Malaysia (UTM) and MOHE are gratefully acknowledged.

\section{References}

[1] Kosmatka S.H., Panarese W.C. and Association P.C. (2002) Design and control of concrete mixtures. Portland Cement Association Skoki, vol. 5420.

[2] Maheshkumar H. Thakrele (2014) Experimental Study on Foam Concrete. International Journal of Civil, Structural, Environmental and Infrastructure Engineering Research and Development, 4(1):145-158.

[3] Jones M.R. and McCarthy A. (2006) Heat of Hydration in Foamed Concrete: Effect of Mix Constituents and Plastic Density. Cement and Concrete Research. 36:1032-1041.

[4] Kearsley E.P. (1996) The use of foamed concrete for affordable development in third world countries. Appropriate Concrete Technology, E \& FN Spon, London, pp. 233-243.

[5] Lim S.K., Tan C.S., Zhao X. and Ling T.C. (2014) Strength and Toughness of Lightweight Foamed Concrete with Different Sand Grading. KSCE Civil Engineering, 19(7):2191-2197.

[6] Md Azree Othuman Mydin (2011) Potential of Using Lightweight Foamed Concrete in Composite Load-Bearing Wall Panels In Low-Rise Construction. Concrete Research Letters 2(2):213-227.

[7] Yasser M. Hunaiti (1997) Strength of Composite Sections with Foamed and Lightweight Aggregate Concrete. Journal of Materials in Civil Engineering, 9(2):58-61.

[8] Nagesh Mustapure and Eramma H. (2014) Experimental Investigation on Cellular Lightweight Concrete Blocks for Varying Grades of Density. International Journal of Advanced Technology in Engineering and Science, 2(8):10-18.

[9] Parhizkar T., Najimi M., Pourkhorshidi A.R. (2012) Application of pumice aggregate in structural lightweight concrete. Asian Journal of Civil Engineering (Building and Housing), 13(1):4354.

[10] Neville A.M.M., Brooks J.J.J. (2010) Concrete Technology. Vol. 11, Building and Environment. p. 442.

[11] Chen Bing, Wu Zhen and Liu Ning (2012) Experimental Research on Properties of High-Strength Foamed Concrete. Journal of Materials in Civil Engineering, 24(1):113-118.

[12] Bing C and Ning L. (2014) Experimental Research on Properties of Fresh and Hardened Rubberized Concrete. Journal of Materials in Civil Engineering, 26(8):1-8.

[13] Kearsley EP, Wainwright PJ. (2001) Porosity and permeability of foamed concrete. Cement and Concrete Research, 31(5):805812.

[14] Hilal A., Thom NH, R. Dawson A. (2015) The Use of Additives to Enhance Properties of Pre- Formed Foamed Concrete. International Journal of Engineering Technology, 7(4):286-293.

[15] Mydin MAO, Sudin MAS, Sani N. (2014) Axial Compressive Strength of Foamcrete with Different Profiles and Dimensions. MATEC Web of Conferences 15, 01020.

[16] Falade F, Ikponmwosa E, Fapohunda C. (2013) A Study on the Compressive and Tensile Strength of Foamed Concrete Containing Pulverized Bone as a Partial Replacement of Cement. Engineering and Applied Science 13:82-93. 
[17] Thakrele MH. Experimental study on foam concrete. International Journal of Civil, Structural, Environmental and Infrastructure Engineering Research and Development, 4(1):145-58.

[18] Noraini M Zahari A Mujahid A Zaidi IAR. (2009) Foamed Concrete: Potential Application in Thermal Insulation. In: Muceet. p. $47-52$

[19] Aini K, Sari M, Rahim A, Sani M. (2017) Applications of Foamed Lightweight Concrete. MATEC Web of Conferences 97, 01097.

[20] Xin Q. (2016) Research Status of Foamed Concrete. International Journal of Multidisciplinary Research Development, 3(4):328330.

[21] Varghese S, Ashok AM, Joseph AK, Emmanuel S, Swathylekshmi O V. (2017) A study on properties of foamed concrete with natural and synthetic foaming agent. International Research Journal of Engineering and Technology, 4(3):2009-2011.

[22] Othuman Mydin MA, Wang YC. (2011) Structural performance of lightweight steel-foamed concretesteel composite walling system under compression. Thin-Walled Structures 49(1):66-76.

[23] Md Azree Othuman Mydin. (2011) Potential of Using Lightweight Foamed Concrete in Composite Load-Bearing Wall Panels In Low-Rise Construction. Concrete Research Letters. 2(2):213-227.

[24] Mydin MAO, Wang YC. (2012) Mechanical properties of foamed concrete exposed to high temperatures. Construction and Building Materials, 26(1):638-54.

[25] Othuman Mydin MA, Wang YC. (2012) Thermal and mechanical properties of lightweight foamed concrete at elevated temperatures. Magazine of Concrete Research, 64(3):213-24

[26] BS EN 12390-7:2009 Testing hardened concrete, Part 7, Density of hardened concrete.

[27] BS 1881-122:2011 Testing concrete Part 122: Method for determination of water absorption. BSI Standards Publication.

[28] BS EN 12390-3:2009 Testing hardened concrete. Part 3, Compressive strength of test specimens.

[29] BS EN 12390-6:2009 Testing hardened concrete. Part 6: Tensile splitting strength of test specimens.

[30] ASTM C869 (91). "Standard Specification for Foaming Agents Used in Making Preformed Foam for Cellular Concrete. 